\title{
Carbon Burial in Young Tropical Reservoirs Is Higher at Lower Latitudes*
}

\author{
Elizabeth Sikar1\#, Marco Aurelio dos Santos², Ana Carolina Moterani³, Isabella Matvienko, \\ Ana Carla Martins Veras', Juliana Pinto Pereira Dias ${ }^{3}$, Orleno Marques da Silva Junior 4,5, \\ Claudio Pavani ${ }^{3}$, Marcelo Amorim ${ }^{3}$, Teodosio das Neves Milisse Nzualo ${ }^{3}$, \\ Ayr Manoel Portilho Bentes Junior ${ }^{3}$, Rogerio Duarte ${ }^{3}$
}

${ }^{1}$ Construmaq São Carlos, São Carlos, SP, Brazil

${ }^{2}$ Programa de Planejamento Energético da Universidade Federal do Rio de Janeiro, Brazil

${ }^{3}$ Laboratório de Energias Renováveis e Estudos Ambientais da Universidade Federal do Rio de Janeiro, Brazil

${ }^{4}$ Instituto de Pesquisas Científicas e Tecnológicas do Estado do Amapá, Brazil

${ }^{5}$ Programa de Pós-Graduação em Geografia da Universidade Federal do Amapá, Brazil

Email: "emsikar@gmail.com

How to cite this paper: Sikar, E., dos Santos, M. A., Moterani, A. C., Matvienko, I., Veras, A. C. M., Dias, J. P. P., da Silva Jr., O. M., Pavani, C., Amorim, M., Nzualo, T. D. N. M., Bentes Jr., A. M. P., \& Duarte, R. (2021). Carbon Burial in Young Tropical Reservoirs Is Higher at Lower Latitudes. Journal of Geoscience and Environment Protection, 9, 84-99.

https://doi.org/10.4236/gep.2021.912006

Received: November 19, 2021

Accepted: December 25, 2021

Published: December 28, 2021

Copyright $\odot 2021$ by author(s) and Scientific Research Publishing Inc. This work is licensed under the Creative Commons Attribution International License (CC BY 4.0).

http://creativecommons.org/licenses/by/4.0/

\begin{abstract}
Man-made environments such as tropical hydroelectric reservoirs alter the preexisting carbon $(\mathrm{C})$ cycle and remove $\mathrm{C}$ from circulation through burial in sediments. Carbon burial (CB) was measured using the silica-tracer method during four field surveys in the less than six-year-old Belo Monte tropical reservoir. Fresh C sedimentation was also measured. Belo Monte's CB median rate $276\left(\mathrm{n}=84 ; \min 0 ; \max 352,625 \mathrm{mg} \mathrm{C} \cdot \mathrm{m}^{-2} \cdot \mathrm{d}^{-1}\right)$ is within the range (230 to $\left.436 \mathrm{mg} \mathrm{C} \cdot \mathrm{m}^{-2} \cdot \mathrm{d}^{-1}\right)$ of $\mathrm{CB}$ rates measured further downstream at the Xingu Ria and higher than the averaged over 50 years oceanic rate $244 \mathrm{mg} \mathrm{C} \cdot \mathrm{m}^{-2} \cdot \mathrm{d}^{-1}$ estimated for an increasingly deoxygenated ocean. Carbon burial median rates of tropical reservoirs with similar age and trophic state correlate inversely with latitude at a rate of $17.5 \mathrm{mg} \mathrm{C} \cdot \mathrm{m}^{-2} \cdot \mathrm{d}^{-1}$ per degree. Carbon burial efficiency of these reservoirs correlates positively with latitude at a ratio of $0.22 \%$ per degree.
\end{abstract}

\section{Keywords}

Carbon, Burial, Sediments, Hydroelectric Reservoirs

\section{Introduction}

Humanity has been changing Earth's landscapes and atmosphere with deforesta-

${ }^{*}$ Carbon burial rates in young tropical hydroelectric reservoirs in Brazil.

${ }^{\#}$ Corresponding author. 
tion, agriculture, resource extraction, overpopulation and flooding. Science and technology contribute with assessments and attempts to prevent and alleviate the state of affairs, such as Awuh (2021)'s identification of adaptation measures employed to combat urban-heat-island effects, Salameh (2021)'s investigation on how a whole groundwater stock can be exhausted by exploitation of deep groundwater resources and Liu et al. (2021)'s proposal for long-term implementation of the sustainable supply chain method to ameliorate the impacts of water diversion projects.

Landscape change comes with altered carbon (C) circulation, such as the originated by hydroelectric reservoir creation (Kopittke et al., 2021; Reynolds, 2021). In these reservoirs autochthonous organic matter is produced (Kunz et al., 2011), carbon burial (CB) can sustain methane emission (Sobek et al., 2012) and unfavorable decomposition conditions promote CB (Isidorova et al., 2019).

Sedimentation rates are controlled by precipitation, water inflow, water residence time and surrounding reservoir land use (Leite, 1998). Quantification of the sediment magnitude and its increase (Lewis et al., 2013; Miranda \& Mauad, 2014; Hilgert \& Fuchs, 2015) and its C concentration can and have been used to determine sedimentary C stock increase (Bernardo et al., 2017). Tropical reservoirs emit more methane (Sikar et al., 2005; Bertassoli et al., 2021) and bury 3 times more carbon (Sikar et al., 2009) compared to the pre-flooded area.

Despite the ongoing debate about incorporation, or not, of $\mathrm{C}$ that is buried by hydroelectric reservoirs, into greenhouse gas inventories (IPCC, 2019) there is increasing action to acknowledge (Mendonça et al., 2012) and quantify C burial rates by these reservoirs (Teodoru et al., 2012; Wang et al., 2019; Phyoe et al., 2020).

Carbon burial rates in man-made tropical reservoirs are significantly higher than those in natural waterbodies. At latitude $19^{\circ} \mathrm{N}$ organic carbon burial average post-1950-to-2013 rates measured in natural oligotrophic high mountain lakes El Sol (60 - $\left.301 \mathrm{mg} \mathrm{C} \cdot \mathrm{m}^{-2} \cdot \mathrm{d}^{-1}\right)$, La Luna $\left(99-263 \mathrm{mg} \mathrm{C} \cdot \mathrm{m}^{-2} \cdot \mathrm{d}^{-1}\right.$ ) (Alcocer et al., 2020) and average early 1980s-2005 rates measured in natural oligotrophic maar Lake Alchichica (41- $71 \mathrm{mg} \mathrm{C} \cdot \mathrm{m}^{-2} \cdot \mathrm{d}^{-1}$ ) (Alcocer et al., 2014) are about up to an order of magnitude smaller than those measured in constructed reservoir Vale de Bravo (eutrophic since 1993) averaged between 1992-2006 (474 - 1041 $\mathrm{mg} \mathrm{C} \cdot \mathrm{m}^{-2} \cdot \mathrm{d}^{-1}$ ) (Carnero-Bravo et al., 2015).

With increasing attention to quantification of anthropogenic $\mathrm{C}$ emissions, it becomes also more imperative to assess the expanding realm of man-caused $\mathrm{C}$ retention rates. In this respect, Hamido et al. (2016) measured significant $C$ storage $\left(252-638 \mathrm{mg} \mathrm{C} \cdot \mathrm{m}^{-2} \cdot \mathrm{d}^{-1}\right)$ in domestic turfgrass lawns in Alabama USA and Dilla et al. (2019) conclude that by increasing the density of $f$. albida trees from 5.80 to $100 \mathrm{ha}^{-1}$ in a tropical parkland $\left(8.5^{\circ} \mathrm{N}\right)$ soil C sequestration could be estimated as $132 \mathrm{mg} \mathrm{C} \cdot \mathrm{m}^{-2} \cdot \mathrm{d}^{-1}$ for 42 years.

The $\mathrm{C}$ sink status of the sediments in man-made reservoirs has long been foreseen by Mulholland \& Elwood (1982) and references therein. Ignoring this C 
sequestration path in global $\mathrm{C}$ inventories is akin to exempting reservoirs from methane emissions.

This present work reports latitude dependences found using carbon burial rates measured in three young tropical Brazilian reservoirs of similar trophic states.

\section{Study Site}

Inaugurated in 2016 the Belo Monte (BM) hydroelectric reservoir is located on the eastern side of the Amazon forest in the Brazilian state of Pará. Its total area is $478 \mathrm{~km}^{2}$ and comprises a main and a secondary reservoir. Built by flooding land along the Xingu River the main reservoir's area is $359 \mathrm{~km}^{2}$. The secondary reservoir was created by flooding $119 \mathrm{~km}^{2}$ of forested terrain with water diverted from the Xingu River through a constructed canal $20 \mathrm{~km}$ long. The dams of both reservoirs shortcut $120 \mathrm{~km}$ of winding river length. The achieved purpose was to flood less land while maximizing the altimetric gradient necessary to generate hydropower. Turbines are at the secondary reservoir dam which is located at $3.1^{\circ} \mathrm{S} 51.7^{\circ} \mathrm{W}$ about $200 \mathrm{~km}$ south from where the Xingu River flows into the Amazon River. The main reservoir's dam controls the water flow of the Xingu River's bypassed stretch. A study conducted prior to flooding classified BM's forming waters as meso-oligotrophic (Camargo \& Ghilardi Jr., 2009). We measured carbon burial rates during four field surveys: from 1) 20 to 24 Aug 2019; 2) 23 to 27 Nov 2020; 3) 22 to 26 May 2021 and 4) 22 to 26 Jun 2021. Measured sites were: three on the Xingu River upstream from the main reservoir, thirteen sites on the main (also known as Xingu) reservoir and eight sites on the secondary (aka intermediary) reservoir (Figure 1).

\section{Materials and Methods}

Three definitions relevant to this work are:

1) OC sedimentation rate is the daily quantity of total (aka "fresh") OC that lands on the sediment. Some of the fresh OC will undergo decomposition and return to circulation while another portion will escape decomposition and remain permanently sedimented.

2) OC burial rate $(\mathrm{CB})$ is the daily amount of $\mathrm{OC}$ that escaped decomposition and therefore is out of the carbon circulation process and is permanently sedimented.

3) Carbon burial efficiency (CBE) is the ratio "organic carbon burial rate/ organic carbon sedimentation rate".

Organic carbon burial rates were measured between Aug 2019 and June 2021 during four field surveys at same 24 investigated sites $(24 \times 4=96 \mathrm{C}$ burial rate measurements). Site depth was measured upon arrival. Field campaigns were carried out on Aug 2019 (20 - 24), Nov 2020 (23 - 27), May 2021 (22 - 26) and Jun 2021 (22 - 26).

Sediments were sampled using a stainless-steel dredge (Figure 2), and after drying weighed with a Gehaka AG200 analytical balance. 


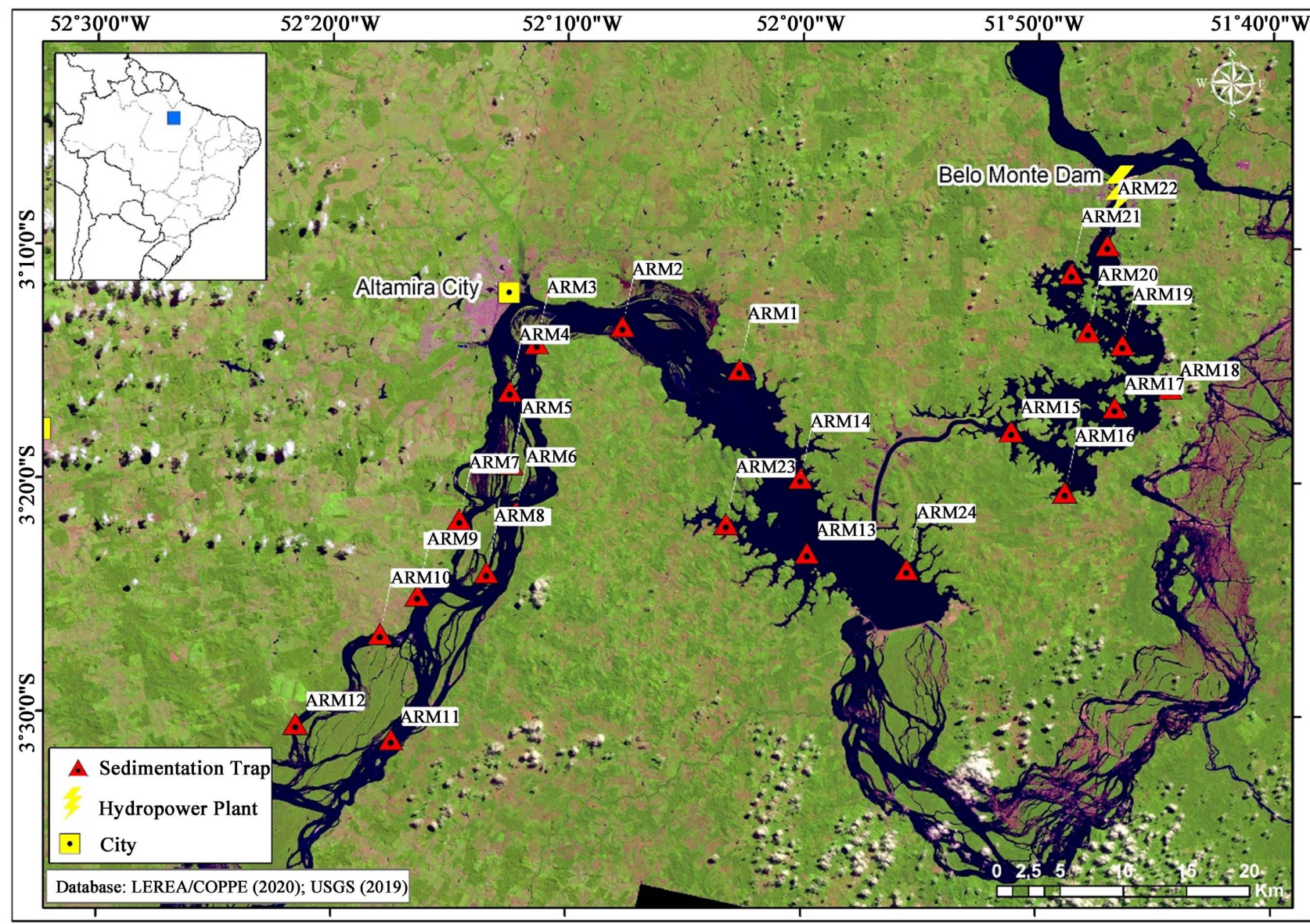

Figure 1. Location of Belo Monte Hydroelectric Reservoir and the 24 sampled sites (ARMadilha de sedimentação = sedimentation trap).

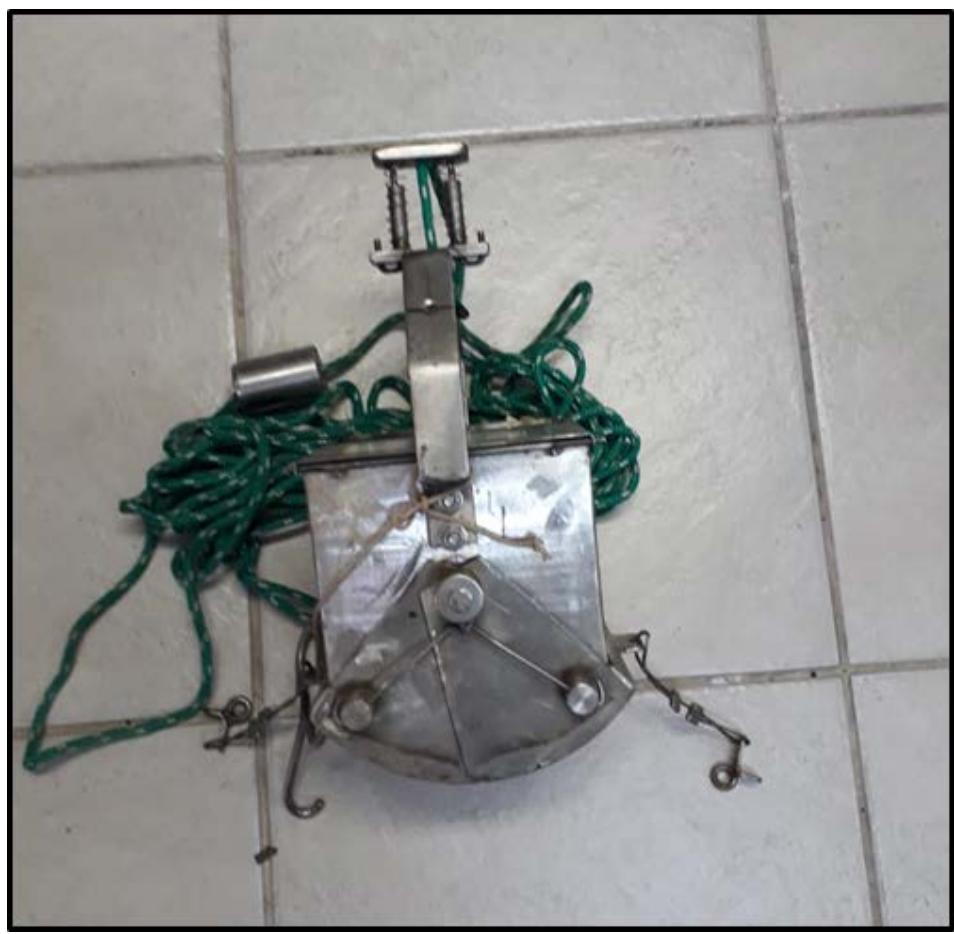

Figure 2. Ekman type dredge used for sediment sampling. 
Silica was used as an OC burial tracer (Sikar et al., 2012). Concomitantly and for the sake of comparison with OC burial rates, fresh OC sedimentation rates were also measured (Sikar et al., 2012).

Sediment dredging and sediment trap deployment procedures were performed at each of the 24 sampled sites (Figure 3 ).

\section{Results and Discussion}

Water median depths were smaller during the second survey and higher during the third, for all three sampled environments (Table S1).

Within Aug 2019-Jun 2021 time span, organic carbon burial rates (Figure 4 and Table S2) were smallest upstream at the Xingu River sites (median $81 \mathrm{mg}$ $\left.\mathrm{C} \cdot \mathrm{m}^{-2} \cdot \mathrm{d}^{-1} ; \mathrm{n}=12 ; \mathrm{min}=9 \mathrm{mg} \mathrm{C} \cdot \mathrm{m}^{-2} \cdot \mathrm{d}^{-1} ; \max =2978 \mathrm{mg} \mathrm{C} \cdot \mathrm{m}^{-2} \cdot \mathrm{d}^{-1}\right)$, highest at the secondary reservoir sites $(767 ; 32 ; 23 ; 48,236)$ and highly variable at the main reservoir sites $(201 ; 52 ; 0 ; 352,625)$. Median of BM (main and secondary environments) collective carbon burial rates was $276(\mathrm{n}=84 ; \min =0 ; \max =$ 352,625).

Possibly due to reservoir youngness, a somewhat generalized paucity of dredgable sediment and even more so of sediment with "expected" appearance (muddy, clayey, layered) was noted. We assumed that with flooding and subsequent sediment layer formation in this young aquatic low latitude environment (the occasionally dredged) vegetation residue was prone to sepultation and thus a valid sediment sample. For example, the last (BM4) survey's highest $\mathrm{CB}$ rate was 15,341 $\mathrm{mg} \mathrm{C} \cdot \mathrm{m}^{-2} \cdot \mathrm{d}^{-1}$ mainly due to high $(50 \%) \mathrm{C}$ concentration in what appeared to be leaf remains (second row fourth sample from left to right, Figure 5). Corroborating our assumption, Sobek et al. (2009) noted the higher likelihood of allochthonous

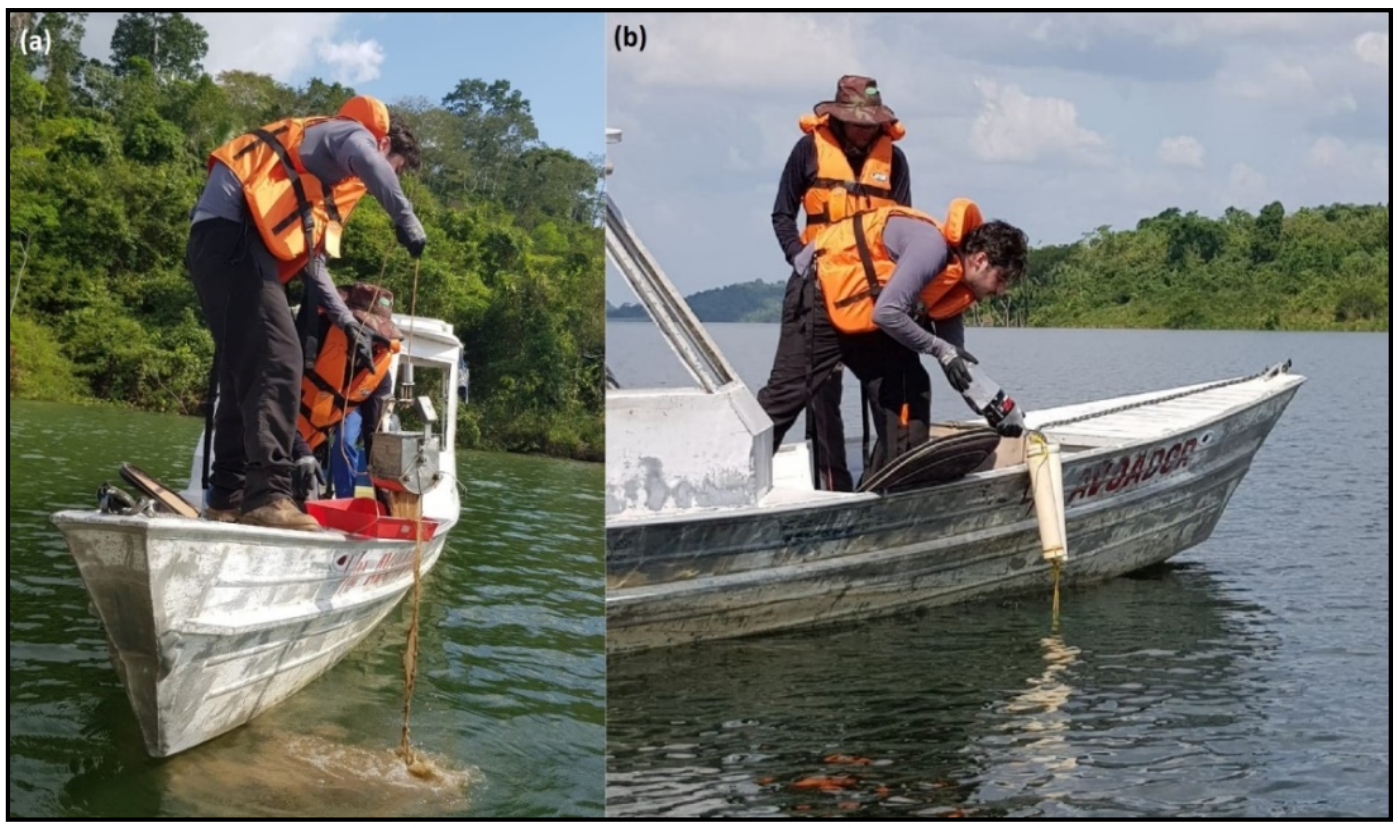

Figure 3. Dredge ready to be lowered from the boat (a) and the sediment-trap-pair deployment (b). The yield of one sediment trap quantifies silica sedimentation rate and fresh OC sedimentation rate the other. 


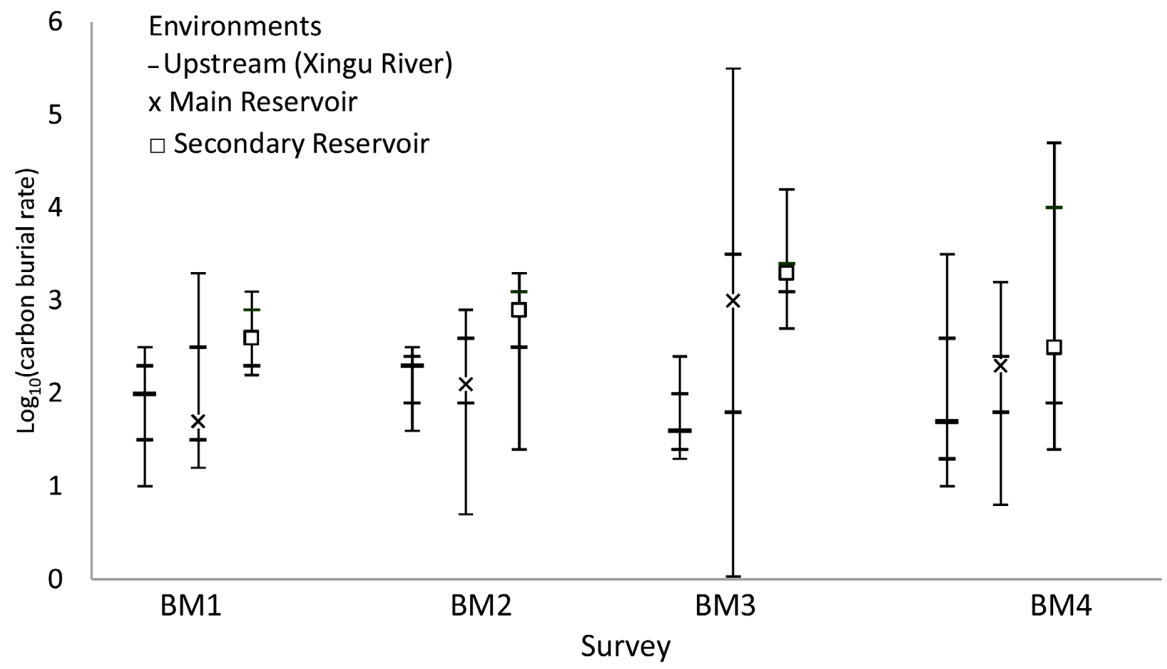

Figure 4. Logarithms of organic carbon burial rates $\left(\mathrm{mg} \mathrm{C} \cdot \mathrm{m}^{-2} \cdot \mathrm{d}^{-1}\right)$ measured during four field campaigns between Aug 2019 and June 2021 at Belo Monte (main and secondary) reservoir and upstream. Highest rate was $352,625 \mathrm{mg} \mathrm{C} \cdot \mathrm{m}^{-2} \cdot \mathrm{d}^{-1} \mathrm{measured}$ at site ARM7 in the main reservoir during the third campaign. Log of minimum, first quartile, median, third quartile and maximum values are shown on each line plot.

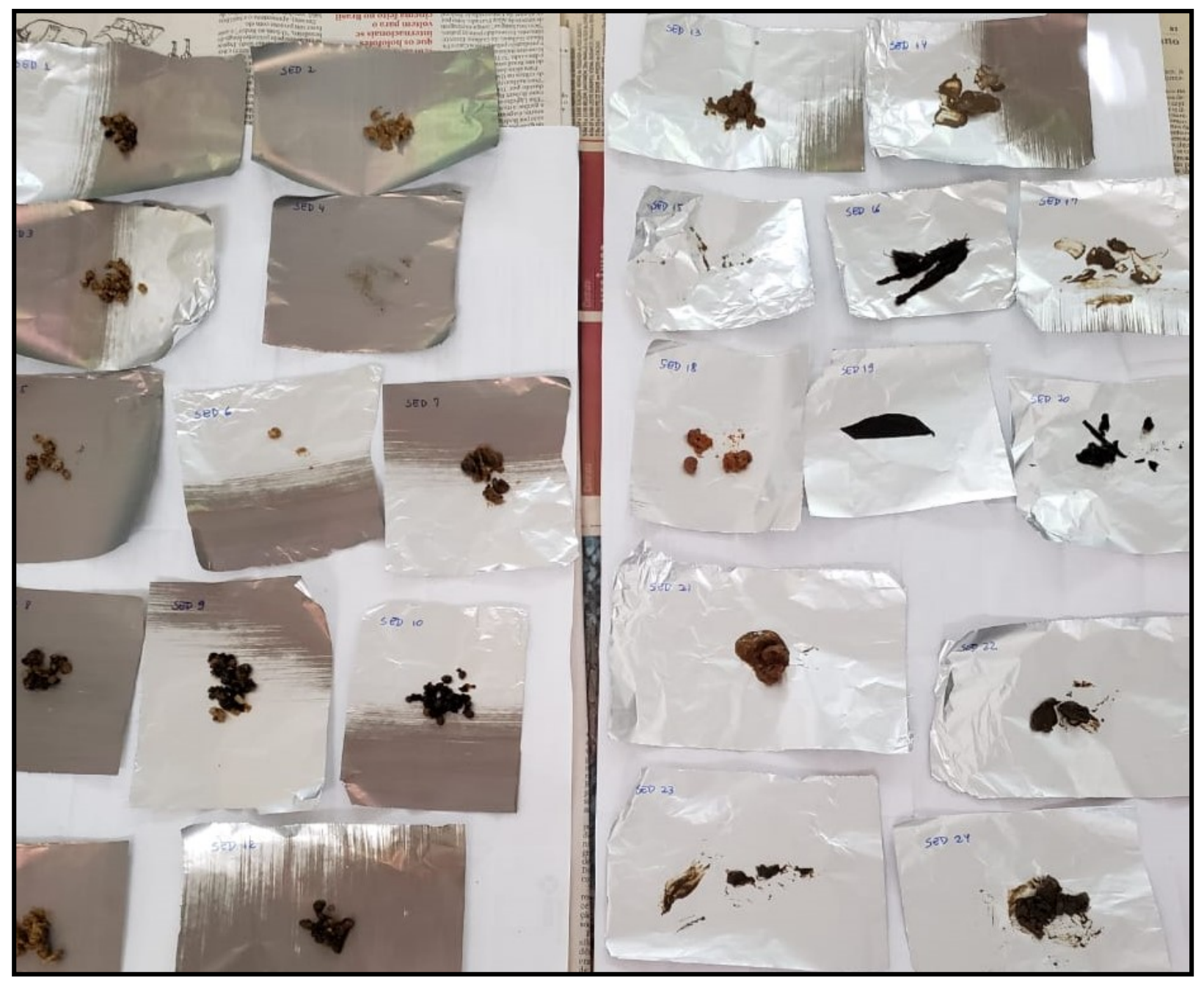

Figure 5. BM4 survey sediment samples from the 24 sites. 
(terrestrial particulate organic carbon) rather than autochthonous organic matter burial in sediments of inland waters and also, vegetal remains have been observed in the $111-88$ and $48-11.5 \mathrm{~cm}$ deep sediment layers of an Amazonia floodplain lake by Moreira-Turcq et al. (2004). However, anthropogenic allochthonous carbon in more severely impacted waterbodies, such as the semi-treated sewage flowed into subtropical eutrophic Lake Donghu located in Wuhan City/ China, might not be as recalcitrant as allochthonous carbon of natural origin (Yang et al., 2008).

Measured CB rates of all four surveys varied between 0 and $352,625 \mathrm{mg}$ $\mathrm{C} \cdot \mathrm{m}^{-2} \cdot \mathrm{d}^{-1}$ (Figure 4 and Table S1). The lower (null) rate is due to the amount of carbon in sediment sample being below the detection limit of the analytical balance. The higher rate is because of the high (54\%) C content in what appeared to be a preserved seed in the sediment sample and the high $\left(10,918 \mathrm{mg} \mathrm{m}^{-2} \cdot \mathrm{d}^{-1}\right) \mathrm{se}-$ dimentation rate of silica.

BM Reservoir's CB median rate $276 \mathrm{mg} \mathrm{C} \cdot \mathrm{m}^{-2} \cdot \mathrm{d}^{-1}$ is higher than those found in tropical reservoirs Serra da Mesa $\left(14^{\circ} \mathrm{S} ;\right.$ median $87 \mathrm{mg} \mathrm{C} \cdot \mathrm{m}^{-2} \cdot \mathrm{d}^{-1} ; \mathrm{n}=14$; min 19 ; $\max 516)$ and Manso $\left(15^{\circ} \mathrm{S} ; 62 ; 9 ; 18 ; 212\right)$ measured when they were between 3.7 and 6.7 years old (Sikar et al., 2012).

This reveals a robust $\left(\mathrm{R}^{2}=0.99\right)$ inverse correlation ratio of $17.5 \mathrm{mg} \mathrm{C} \cdot \mathrm{m}^{-2} \cdot \mathrm{d}^{-1}$ per degree South, for young tropical hydroelectric meso-oligotrophic reservoirs located between $3^{\circ} \mathrm{S}$ and $15^{\circ} \mathrm{S}$ in Brazil (Figure 6). If the burial efficiency increase rate of $0.22 \% \mathrm{yr}^{-1}$ measured in tropical reservoirs almost two decades ago (Sikar et al., 2012) holds it can be used with the inverse correlation ratio $17.5 \mathrm{mg}$ $\mathrm{C} \cdot \mathrm{m}^{-2} \cdot \mathrm{d}^{-1}$ per degree South here obtained to predict burial rates in tropical reservoirs of similar characteristics e.g. flooded land type and trophic state. $\mathrm{Cu}-$ ruá-Una is a hydroelectric oligotrophic reservoir inaugurated in 1977 (44 years old) located $266 \mathrm{~km} \mathrm{NW}$ of BM and only $0.5^{\circ}$ north. Assuming it buried a "corrected for latitude" $276 \mathrm{mg} \mathrm{C} \cdot \mathrm{m}^{-2} \cdot \mathrm{d}^{-1}$ when it was 5 years old (as BM) an estimate

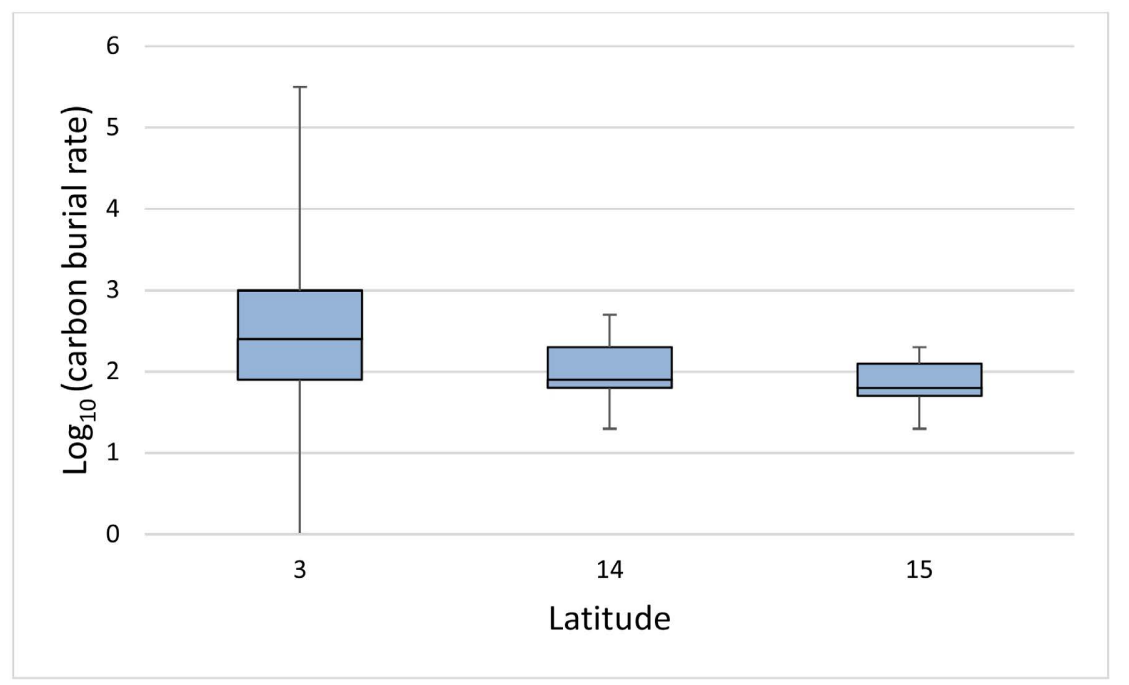

Figure 6. Logarithms of carbon burial rates $\left(\mathrm{mg} \mathrm{C} \cdot \mathrm{m}^{-2} \cdot \mathrm{d}^{-1}\right)$ measured in three young tropical $\left({ }^{\circ} \mathrm{S}\right)$ meso-oligotrophic reservoirs in Brazil. 
for this year (2021) is:

$$
\begin{aligned}
& {\left[276 \mathrm{mg} \mathrm{C} \cdot \mathrm{m}^{-2} \cdot \mathrm{d}^{-1}+\left(17.5 \mathrm{mg} \mathrm{C} \cdot \mathrm{m}^{-2} \cdot \mathrm{d}^{-1}{ }^{\circ} S^{-1} \times(0.5)^{\circ} \mathrm{S}\right)\right] \times\left[1.0022^{44-5}\right]} \\
& =310 \mathrm{mg} \mathrm{C} \cdot \mathrm{m}^{-2} \cdot \mathrm{d}^{-1}
\end{aligned}
$$

In comparison, lifetime average carbon burial rates measured in Curuá-Una 4 years ago using a linear model of sediment accumulation rate and organic carbon accumulation rate yielded a $20 \%$ smaller rate $\left(249 \mathrm{mg} \mathrm{C} \cdot \mathrm{m}^{-2} \cdot \mathrm{d}^{-1}\right.$ (Quadra et al., 2020) than what we estimated for this present year 2021 (Equation (1)).

The CB/latitude ratio here noted will not hold as trophic states increase. In extreme cases sediment dredging is necessary in order to restore volume capacity. This was observed in the subtropical urban stretches $\left(23.5^{\circ} \mathrm{S}-23.6^{\circ} \mathrm{S}\right)$ of Brazilian rivers Tietê and Pinheiros both located in the megacity of São Paulo and both with high emissions of methane and carbon dioxide, $>5 \%$ nitrogen concentration in bubbles (Sikar et al., 2019) and high concentrations of ammonium (>15 mg N-NH $\mathrm{N}_{4}^{+} \quad \mathrm{L}^{-1}$; (Cetesb, 2012)). Although located within the same basin these two riverine urban stretches are heavily impacted by different sources such as domestic effluents and industrial waste disposal in Tietê and insecticides in Pinheiros (Cunha et al., 2011). Extremely high burial rates of 879,153 $\mathrm{mg}$ $\mathrm{C} \cdot \mathrm{m}^{-2} \cdot \mathrm{d}^{-1}$ in Tietê and $271,437 \mathrm{mg} \mathrm{C} \cdot \mathrm{m}^{-2} \cdot \mathrm{d}^{-1}$ in Pinheiros were measured in year 2012 (unpublished results).

Arctic lakes bury average rates of $10 \mathrm{mg} \mathrm{C} \cdot \mathrm{m}^{-2} \cdot \mathrm{d}^{-1}$ (Anderson et al., 2019) and 8.4 to $37 \mathrm{mg} \mathrm{C} \cdot \mathrm{m}^{-2} \cdot \mathrm{d}^{-1}$ (Sobek et al., 2014), natural and constructed wetlands in northern regions of the northern hemisphere accumulate carbon in their sediments at rates varying between 8.2 and $6027 \mathrm{mg} \mathrm{C} \cdot \mathrm{m}^{-2} \cdot \mathrm{d}^{-1}$ (Table 2 in (Kayranli et al., 2010)) and high mountain tropical lakes bury average rates of 60 to $301 \mathrm{mg}$ $\mathrm{C} \cdot \mathrm{m}^{-2} \cdot \mathrm{d}^{-1}$ (Alcocer et al., 2020). This roughly points to a background tendency of increasing carbon burial with decreasing latitude, in - albeit experiencing human activity intervention-primarily natural sediments.

Estimated C burial rates ranged between 408 and $995 \mathrm{mg} \mathrm{C} \cdot \mathrm{m}^{-2} \cdot \mathrm{d}^{-1}$ in the USA man-made reservoirs located between latitudes $25^{\circ} \mathrm{N}$ and $50^{\circ} \mathrm{N}$ and longitudes $67^{\circ} \mathrm{W}$ and $125^{\circ} \mathrm{W}$ (Figure 3D in (Clow et al., 2015)). There, only a tenuous (if any) latitude dependence but a much stronger longitude-carbon burial rates increasing from east to west - dependence can be noted. Ranking high in CB is Acton Lake, a hypereutrophic hard-water $2.5 \mathrm{~km}^{2}$ lake constructed in 1957 at latitude $39^{\circ} \mathrm{N}$ in southwestern Ohio USA, with $932 \mathrm{mg} \mathrm{C} \cdot \mathrm{m}^{-2} \cdot \mathrm{d}^{-1}$ (Knoll et al., 2013). This potentially shows how the CB latitude dependence can be unobservable when comparing constructed reservoirs of different trophic states and characteristics.

Carbon burial efficiency is defined and approached in more than one way. For instance, non-mineralized organic carbon burial efficiencies are better constrained through refinement of the power law that describes organic carbon oxidation by incorporating the exposure time of sediments to oxygen (Katsev \& Crowe, 2015). More, due to lack of available data on organic matter settling rates, Alin \& Johnson (2007) defined CBE as the fraction of primary production 
that is buried in the sediments of the large lacustrine waterbodies investigated in their study.

Using the CBE here defined (Materials and Methods) the upstream, a more river-like environment, had the smallest CBE median (1.3\%) and the secondary reservoir had the highest (16.3\%; Table S3). The median carbon burial efficiency of young tropical meso-oligotrophic reservoirs has a positive correlation ratio with latitude of $0.22 \%$ per degree south. The data used for this estimate is from Manso Reservoir $\left(15^{\circ} \mathrm{S} ; 6.3 \%\right)$ in Table 1 of Sikar et al. (2012) and the here reported $3.7 \%$ (Table S3).

The silica-tracer method was devised to obtain higher temporally resolved estimations of $\mathrm{CB}$ to compare with daily emissions of greenhouse gases.

In spite of this method being used to measure present day $\mathrm{CB}$ rates the $276 \mathrm{mg}$ $\mathrm{C} \cdot \mathrm{m}^{-2} \cdot \mathrm{d}^{-1}$ median here reported is also within the 230 to $436 \mathrm{mg} \mathrm{C} \cdot \mathrm{m}^{-2} \cdot \mathrm{d}^{-1}$ range found in the Xingu Ria (Bertassoli et al., 2017) downstream from BM measured with dating methods that yield retroactive burial rates.

Interestingly and for contextualization sake, median $276 \mathrm{mg} \mathrm{C} \cdot \mathrm{m}^{-2} \cdot \mathrm{d}^{-1}$ is $13 \%$ higher than the oceanic carbon burial 50-year-average rate upscaled for the entire oceanic area $359 \times 10^{6} \mathrm{~km}^{2}$ (about $244 \mathrm{mg} \mathrm{C} \cdot \mathrm{m}^{-2} \cdot \mathrm{d}^{-1}$ ) that we estimated based on the ocean's expanding zones of minimum oxygen's impact on oceanic C burial calculated by Baroni et al. (2020).

\section{Conclusion}

A robust $\left(\mathrm{R}^{2}=0.99\right)$ inverse correlation of $17.5 \mathrm{mg} \mathrm{C} \cdot \mathrm{m}^{-2} \cdot \mathrm{d}^{-1}$ per ${ }^{\circ} \mathrm{S}$ between carbon burial rate and tropical latitude was found in young tropical man-fabricated meso-oligotrophic reservoirs situated between latitudes $3^{\circ} \mathrm{S}$ and $15^{\circ} \mathrm{S}$. While carbon burial rate decreases with increasing latitudes, carbon burial efficiency (here defined as ratio total-organic-carbon-buried-in-sediment/total-organic-carbonlanded-on-sediment) increases with increasing latitude at $0.22 \%$ per ${ }^{\circ} \mathrm{S}$.

Younger than six-year-old BM Reservoir presently buries carbon at median rate $276(\mathrm{n}=84 ; \min 0 ; \max 352,625) \mathrm{mg} \mathrm{C} \cdot \mathrm{m}^{-2} \cdot \mathrm{d}^{-1}$ and lands carbon on its sediment layer at median rate $5818(81 ; 604 ; 79,932) \mathrm{mg} \mathrm{C} \cdot \mathrm{m}^{-2} \cdot \mathrm{d}^{-1}$.

Belo Monte Reservoir's carbon burial median rate here obtained is within the lower range of buried carbon rates measured in the Xingu Ria further downstream.

For the purpose of carbon inventories if burial rates of carbon downstream of the dam have increased (or decreased) since the reservoir creation then $\mathrm{C}$ burial attributable to the reservoir could be higher (or lower) than the measured rate here reported.

Finally, quantifying not only the carbon sink rates but also the circulating carbon will better constrain the carbon budget of man-made environments.

\section{Acknowledgements}

This investigation of carbon fluxes in Belo Monte Hydroelectric Reservoir is 
funded by the R\&D Project "Development of a Methodology for the Calculation of Greenhouse Gas Emissions in the Reservoir of the Belo Monte HPP, Norte Energia, ANEEL code PD-07427-0119/2019”. And GEP's review comments, to which we are grateful, improved this manuscript.

\section{Conflicts of Interest}

The authors declare no conflicts of interest regarding the publication of this paper.

\section{References}

Alcocer, J., Ruiz-Fernández, A. C., Escobar, E., Pérez-Bernal, L. H., Oseguera, L. A., \& Ardiles Gloria, V. (2014). Deposition, Burial and Sequestration of Carbon in an Oligotrophic, Tropical Lake. Journal of Limnology, 73, 223-235.

https://doi.org/10.4081/jlimnol.2014.783

Alcocer, J., Ruiz-Fernández, A. C., Oseguera, L. A., Caballero, M., Sanchez-Cabeza, J-Albert., Pérez-Bernal, L. H., \& Hernández-Rivera, D. M. (2020). Sediment Carbon Storage Increases in Tropical, Oligotrophic, High Mountain Lakes. Anthropocene, 32, Article ID: 100272. https://doi.org/10.1016/j.ancene.2020.100272

Alin, S., \& Johnson, T. C. (2007). Carbon Cycling in Large Lakes of the World: A Synthesis of Production, Burial, and Lake-Atmosphere Exchange Estimates. Global Biogeochemical Cycles, 21, Article No. GB3002. https://doi.org/10.1029/2006GB002881

Anderson, N. J., Appleby, P. G., Bindler, R., Renberg, I., Conley, D. J., Fritz, S. C., Jones, V. J., Whiteford, E. J., \& Yang, H. (2019). Landscape-Scale Variability of Organic Carbon Burial by SW Greenland Lakes. Ecosystems, 22, 1706-1720. https://doi.org/10.1007/s10021-019-00368-8

Awuh, M. E. (2021). Monitoring Day and Night-Time Situation of Urban Heat Island and Possible Adaptation Measures in Douala, Cameroon. Journal of Geoscience and Environment Protection, 9, 163-176. https://doi.org/10.4236/gep.2021.98011

Baroni, I. R., Palastanga, V., \& Slomp, C. P. (2020). Enhanced Organic Carbon Burial in Sediments of Oxygen Minimum Zones upon Ocean Deoxygenation. Frontiers in Marine Science, 6, Article No. 839. https://doi.org/10.3389/fmars.2019.00839

Bernardo, J. W. Y., Mannich, M., Hilgert, S., Fernandes, C. V. S., \& Bleninger, T. (2017). A Method for the Assessment of Long-Term Changes in Carbon Stock by Construction of a Hydropower Reservoir. Ambio, 46, 566-577. https://doi.org/10.1007/s13280-016-0874-6

Bertassoli Junior, D. J., de Araújo, K. R., de Camargo, M. G. P., Alem, V. A. T., Pereira, T. S., Krusche, A. V., Bastviken, D., Richey, J. E., Sawakuchi, A. O., \& Sawakuchi, H. O. (2021). How Green Can Amazon Hydropower Be? Net Carbon Emission from the Largest Hydropower Plant in Amazonia. Science Advances, 7, Article No. eabe1470. https://doi.org/10.1126/sciadv.abe1470

Bertassoli Junior, D. J., Sawakuchi, A. O., Sawakuchi, H. O., Pupim, F. N., Hartmann, G. A., McGlue, M. M., Chiessi, C. M., Zabel, M., Schefuß, E., Pereira, T. S., Santos, R. A., Faustino, S. B., Oliveira, P. E., \& Bicudo, D. C. (2017). The Fate of Carbon in Sediments of the Xingu and Tapajós Clearwater Rivers, Eastern Amazon. Frontiers in Marine Science, 4, Article No. 44. https://doi.org/10.3389/fmars.2017.00044

Camargo, M., \& Ghilardi Jr., R. (2009). Construction of an Ecological Model for the Middle Xingu River-A Tool for Forecasting Future Scenarios. (In Portuguese) https://www.cgti.org.br/publicacoes/wp-content/uploads/2016/03/Construc\%CC\%A7a 
\%CC\%83o-de-um-modelo-ecolo\%CC\%81gico-para-o-me\%CC\%81dio-rio-Xingu-instr umento-na-previsa\%CC\%83o-de-cena\%CC\%81rios-futuros.pdf

Carnero-Bravo, V., Merino-Ibarra, M., Ruiz-Fernández, A. C., Sánchez-Cabeza, J. A., \& Ghaleb, B. (2015). Sedimentary Record of Water Column Trophic Conditions and Sediment Carbon Fluxes in a Tropical Water Reservoir (Valle de Bravo, Mexico). Environmental Science Pollution Research, 22, 4680-4694.

https://doi.org/10.1007/s11356-014-3703-0

CETESB State of São Paulo's Environmental Agency (2012). Report of Surface Water's Quality in the Brazilian State of São Paulo. (In Portuguese) https://cetesb.sp.gov.br/

Clow, D. W., Stackpoole, S. M., Verdin, K. L., Butman, D. E., Zhu, Z., Krabbenhoft, D. P., \& Striegl, R. G. (2015). Organic Carbon Burial in Lakes and Reservoirs of the Conterminous United States. Environmental Science \& Technology, 49, 7614-7622. https://doi.org/10.1021/acs.est.5b00373

Cunha, D. G. F., Grull, D., Damato, M., Blum, J. R. C., Eiger, S., Lutti, J. E. I., \& Mancuso, P. C. S. (2011). Contiguous Urban Rivers Should Not Be Necessarily Submitted to the Same Management Plan: The Case of Tietê and Pinheiros Rivers (São Paulo-Brazil). Anais da Academia Brasileira de Ciências, 83, 1465-1479. https://doi.org/10.1590/S0001-37652011000400032

Dilla, A. M., Smethurst, P. J., Barry, K., \& Parsons, D. (2019). Preliminary Estimate of Carbon Sequestration Potential of Faidherbia albida (Delile) A. Chev in an Agroforestry Parkland in the Central Rift Valley of Ethiopia. Forests, Trees and Livelihoods, 28, 79-89. https://doi.org/10.1080/14728028.2018.1564146

Hamido, S. A., Guertal, E. A., \& Wesley Wood, C. (2016). Carbon Sequestration under Warm Season Turfgrasses in Home Lawns. Journal of Geoscience and Environment Protection, 4, 53-63. https://doi.org/10.4236/gep.2016.49005

Hilgert, S., \& Fuchs, S. (2015). Static and Dynamic Hydro-Acoustic Assessment of Sediment Magnitudes in a Brazilian Reservoir. In Proceedings of Acoustics in Underwater Geosciences Symposium (pp. 1-5). Institute of Electrical and Electronics Engineers. https://doi.org/10.1109/RIOAcoustics.2015.7473584

Intergovernmental Panel on Climate Change (IPCC) (2019). Chapter 7: Wetlands. In 2019 Refinement to the 2006 IPCC Guidelines for National Greenhouse Gas Inventories. Volume 4: Agriculture, Forestry and Other Land Use (pp. 1-52). Intergovernmental Panel on Climate Change.

https://www.ipcc-nggip.iges.or.jp/public/2019rf/pdf/4_Volume4/19R_V4_Ch07_Wetla $\underline{\text { nds.pdf }}$

Isidorova, A., Mendonça, R., \& Sobek, S. (2019). Reduced Mineralization of Terrestrial OC in Anoxic Sediment Suggests Enhanced Burial Efficiency in Reservoirs Compared to Other Depositional Environments. Journal of Geophysical Research Biogeosciences, 124, 678-688. https://doi.org/10.1029/2018JG004823

Katsev, S., \& Crowe, S. A. (2015). Organic Carbon Burial Efficiencies in Sediments: The Power Law of Mineralization Revisited. Geology, 43, 607-610. https://doi.org/10.1130/G36626.1

Kayranli, B., Scholz, M., Mustafa, A., \& Hedmark, Å. (2010). Carbon Storage and Fluxes within Freshwater Wetlands: A Critical Review. Wetlands, 30, 111-124.

https://doi.org/10.1007/s13157-009-0003-4

Knoll, L. B., Vanni, M. J., Renwick, W. H., Dittman, E. K., \& Gephart J. A. (2013). Tem-

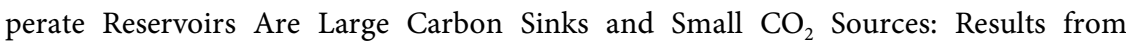
High-Resolution Carbon Budgets. Global Biogeochemical Cycles, 27, 52-64.

https://doi.org/10.1002/gbc.20020 
Kopittke, P., Menzies, N., Dalal, R., McKenna, B., Husted, S., Wang, P., \& Lombi, E. (2021). The Role of Soil in Defining Planetary Boundaries and the Safe Operating Space for Humanity. Environment International, 146, Article ID: 106245. https://doi.org/10.1016/j.envint.2020.106245

Kunz, M. J., Wüest, A., Wehrli, B., Landert, J., \& Senn, D. B. (2011). Impact of a Large Tropical Reservoir on Riverine Transport of Sediment, Carbon, and Nutrients to Downstream Wetlands. Water Resources Research, 47, Article ID: W12531. https://doi.org/10.1029/2011WR010996

Leite, M. A. (1998). Spatial and Temporal Variation of the Sedimentation Rate in Salto Grande Reservoir (Americana-SP) and Its Influence on the Limnological Characteristics of the System. Master's Dissertation, Engineering School of São Carlos, University of São Paulo State. (In Portuguese)

Lewis, S. E., Bainbridge, Z. T., Kuhnert, P. M., Sherman, B. S., Henderson, B., Dougall, C., Cooper, M., \& Brodie, J. E. (2013). Calculating Sediment Trapping Efficiencies for Reservoirs in Tropical Settings: A Case Study from the Burdekin Falls Dam, NE Australia. Water Resources Research, 49, 1017-1029. https://doi.org/10.1002/wrcr.20117

Liu, M., Yang, L. W., \& Liu, T. S. (2021). Analysis on the Structure of Influencing Factors of Sustainable Supply Chain Implementation of Water Diversion Project. Journal of Geoscience and Environmental Protection, 9, 140-150. https://doi.org/10.4236/gep.2021.98009

Mendonça, R., Kosten, S., Sobek, S., Barros, N., Cole, J. J., Tranvik, L. J., \& Roland, F. (2012). Hydroelectric Carbon Sequestration. Nature Geoscience, 5, 838-840. https://doi.org/10.1038/ngeo1653

Miranda, R. B. D., \& Mauad, F. F. I. (2014). Influence of Sedimentation on Hydroelectric Power Generation: Case Study of a Brazilian Reservoir. Journal of Energy Engineering, 141, Article ID: 04014016. https://doi.org/10.1061/(ASCE)EY.1943-7897.0000183

Moreira-Turcq, P., Jouanneau, J. M., Turcq, B., Seyler, P., Weber, O., \& Guyot, J. L. (2004). Carbon Sedimentation at Lago Grande de Curuai, a Floodplain Lake in the Low Amazon Region: Insights into Sedimentation Rates. Palaeogeography, Palaeoclimatology, Palaeoecology, 214, 27-40. https://doi.org/10.1016/j.palaeo.2004.06.013

Mulholland, P. J., \& Elwood, J. W. (1982). The Role of Lake and Reservoir Sediments as Sinks in the Perturbed Global Carbon Cycle. Tellus, 34, 490-499. https://doi.org/10.3402/tellusa.v34i5.10834

Phyoe, W. W., Qin, Y., Yu, N., \& Wang, F. (2020). Sediment Distribution and Organic Carbon Burial in a Subtropical Hydroelectric Reservoir. Aquatic Sciences, 82, Article No. 65. https://doi.org/10.1007/s00027-020-00738-8

Quadra, G. R., Sobek, S., Paranaíba, J. R., Isidorova, A., Roland, F., do Vale, R., \& Mendonça, R. (2020). High Organic Carbon Burial but High Potential for Methane Ebullition in the Sediments of an Amazonian Hydroelectric Reservoir. Biogeosciences, 17, 1495-1505. https://doi.org/10.5194/bg-17-1495-2020

Reynolds, J. (2021). Earth System Interventions as Technologies of the Anthropocene. Environmental Innovation and Societal Transitions, 40, 132-146. https://doi.org/10.1016/j.eist.2021.06.010

Salameh, E. (2021). The Hydrogeological Consequences of the Proposed Extraction of the Deep Groundwater in Jordan. Journal of Geoscience and Environment Protection, 9, 111-128. https://doi.org/10.4236/gep.2021.98007

Sikar, E., dos Santos, M. A., \& dos Santos, E. O. (2019). An Empirical Model for Dinitrogen gas Emission from Inland Waters. Atmospheric and Climate Sciences, 9, 1-25. https://doi.org/10.4236/acs.2019.91001 
Sikar, E., Matvienko, B., dos Santos, M. A., Patchineelam, S. R., Santos, E. O., Silva, M. B., Rocha, C. H. E. D., Cimbleris, A. C. P., \& Rosa, L. P. (2012). Silicon as a Permanent-Carbon Sedimentation Tracer. Inland Waters, 2, 119-128.

https://doi.org/10.5268/IW-2.3.465

Sikar, E., Matvienko, B., Santos, M. A., Rosa, L., Silva, M. B., dos Santos, E., Rocha, C. H. E. D., \& Bentes Jr., A. P. (2009). Tropical Reservoirs Are Bigger Carbon Sinks than Soils. Internationale Vereinigung für Theoretische und Angewandte Limnologie: Verhandlungen, 30, 838-840. https://doi.org/10.1080/03680770.2009.11902252

Sikar, E., Santos, M. A., Matvienko, B., Silva, M. B., Rocha, C. H. E. D., Santos, E., Bentes Jr., A. P., \& Rosa L. P. (2005). Greenhouse Gases and Initial Findings on the Carbon Circulation in Two Reservoirs and Their Watersheds. Internationale Vereinigung für Theoretische und Angewandte Limnologie: Verhandlungen, 29, 573-576. https://doi.org/10.1080/03680770.2005.11902741

Sobek, S., Anderson, N. J., Bernasconi, S. M., \& Del Sontro, T. (2014). Low Organic Carbon Burial Efficiency in Arctic Lake Sediments. Journal of Geophysical Research: Biogeosciences, 119, 1231-1243. https://doi.org/10.1002/2014JG002612

Sobek, S., DelSontro, T., Wongfun, N., \& Wehrli, B. (2012). Extreme Organic Carbon Burial Fuels Intense Methane Bubbling in a Temperate Reservoir. Geophysical Research Letters, 39, 2419-2425. https://doi.org/10.1029/2011GL050144

Sobek, S., Durisch-Kaiser, E., Zurbrügg, R., Wongfun, N., Wessels, M., Pasche, N., \& Wehrli, B. (2009). Organic Carbon Burial Efficiency in Lake Sediments Controlled by Oxygen Exposure Time and Sediment Source. Limnology and Oceanography, 54, 2243-2254. https://doi.org/10.4319/lo.2009.54.6.2243

Teodoru, C. R., Bastien, J., Bonneville, M.-C., Del Giorgio, P. A., Demarty, M., Garneau, M., Hélie, J.-L., Pelletier, L., Prairie, Y. T., Roulet, N. T., Strachan, I. B., \& Tremblay, A. (2012). The Net Carbon Footprint of a Newly Created Boreal Hydroelectric Reservoir. Global Biogeochemical Cycles, 26, Article ID: GB2016.

https://doi.org/10.1029/2011GB004187

Wang, F., Lang, Y. C., Liu, C. Q., Qin, Y., Yu, N. X., \& Wang, B. L. (2019). Flux of Organic Carbon Burial and Carbon Emission from a Large Reservoir: Implications for the Cleanliness Assessment of Hydropower. Science Bulletin, 64, 603-611. https://doi.org/10.1016/j.scib.2019.03.034

Yang, H., Xing, Y., Xie, P., Ni, L., \& Rong, K. (2008). Carbon Source/Sink Function of a Subtropical, Eutrophic Lake Determined from an Overall Mass Balance and a Gas Exchange and Carbon Burial Balance. Environmental Pollution, 151, 559-568.

https://doi.org/10.1016/j.envpol.2007.04.006 
Carbon Burial in Young Tropical Reservoirs is Higher at Lower Latitudes-Supplementary Information

Table S1. Measured depths during each of the four surveys.

\begin{tabular}{|c|c|c|c|c|c|}
\hline \multirow[t]{2}{*}{ Location } & \multirow[t]{2}{*}{ Site } & \multicolumn{4}{|c|}{ Depth (m) } \\
\hline & & 1 & 2 & 3 & 4 \\
\hline \multirow{3}{*}{$\begin{array}{c}\text { Up } \\
\text { stream }\end{array}$} & ARM12 & 5.1 & 3.7 & 10.6 & 8.1 \\
\hline & ARM11 & 2.0 & 2.2 & 6.5 & 7.1 \\
\hline & ARM10 & 5.2 & 5.6 & 10.4 & 7.1 \\
\hline Upstream median & & 5.1 & 3.7 & 10.4 & 7.1 \\
\hline \multirow{13}{*}{$\begin{array}{l}\text { Xingu Reservoir } \\
\text { (Main Reservoir) }\end{array}$} & ARM9 & 3.5 & 4.5 & 6.9 & 6.8 \\
\hline & ARM8 & 4.4 & 1.6 & 3.5 & 4.5 \\
\hline & ARM7 & 3.0 & 1.0 & 5.8 & 3.8 \\
\hline & ARM6 & 3.6 & 1.4 & 6.0 & 4.0 \\
\hline & ARM5 & 4.4 & 2.0 & 6.6 & 4.0 \\
\hline & ARM4 & 6.3 & 2.4 & 7.5 & 7.0 \\
\hline & ARM3 & 11.2 & 7.7 & 3.7 & 11.7 \\
\hline & ARM2 & 9.9 & 8.5 & 8.5 & 10.2 \\
\hline & ARM1 & 5.7 & 2.0 & 7.1 & 5.8 \\
\hline & ARM14 & 9.6 & 5.4 & 10.1 & 9.9 \\
\hline & ARM23 & 5.6 & 2.0 & 5.7 & 5.2 \\
\hline & ARM13 & 18.2 & 13.2 & 15.0 & 17.7 \\
\hline & ARM24 & 14.0 & 9.4 & 11.7 & 8.7 \\
\hline Main R. median & & 5.7 & 2.4 & 6.9 & 6.8 \\
\hline \multirow[t]{8}{*}{ Secondary Reservoir } & ARM15 & 5.5 & 2.3 & $\ldots^{\mathrm{A}}$ & 6.0 \\
\hline & ARM16 & 15.3 & 11.9 & $\ldots^{\mathrm{A}}$ & 14.2 \\
\hline & ARM17 & 30.0 & 18.4 & $\ldots^{\mathrm{A}}$ & 18.7 \\
\hline & ARM18 & 17.0 & 41.1 & 46.4 & 49.1 \\
\hline & ARM19 & 32.1 & 20.6 & 29.7 & 29.7 \\
\hline & ARM20 & 17.6 & 26.9 & 13.7 & 12.4 \\
\hline & ARM21 & 26.9 & 17.9 & 24.1 & 29.5 \\
\hline & ARM22 & 43.9 & 40.0 & 41.7 & 29.0 \\
\hline S. R. median & & 22.3 & 19.5 & 29.7 & 23.9 \\
\hline
\end{tabular}

${ }^{\mathrm{A}}$ Not measured. 
Table S2. Carbon and silica concentrations measured in sediment samples, carbon burial rate and carbon and silica depositional rates measured at sampled sites during each of the four field campaigns.

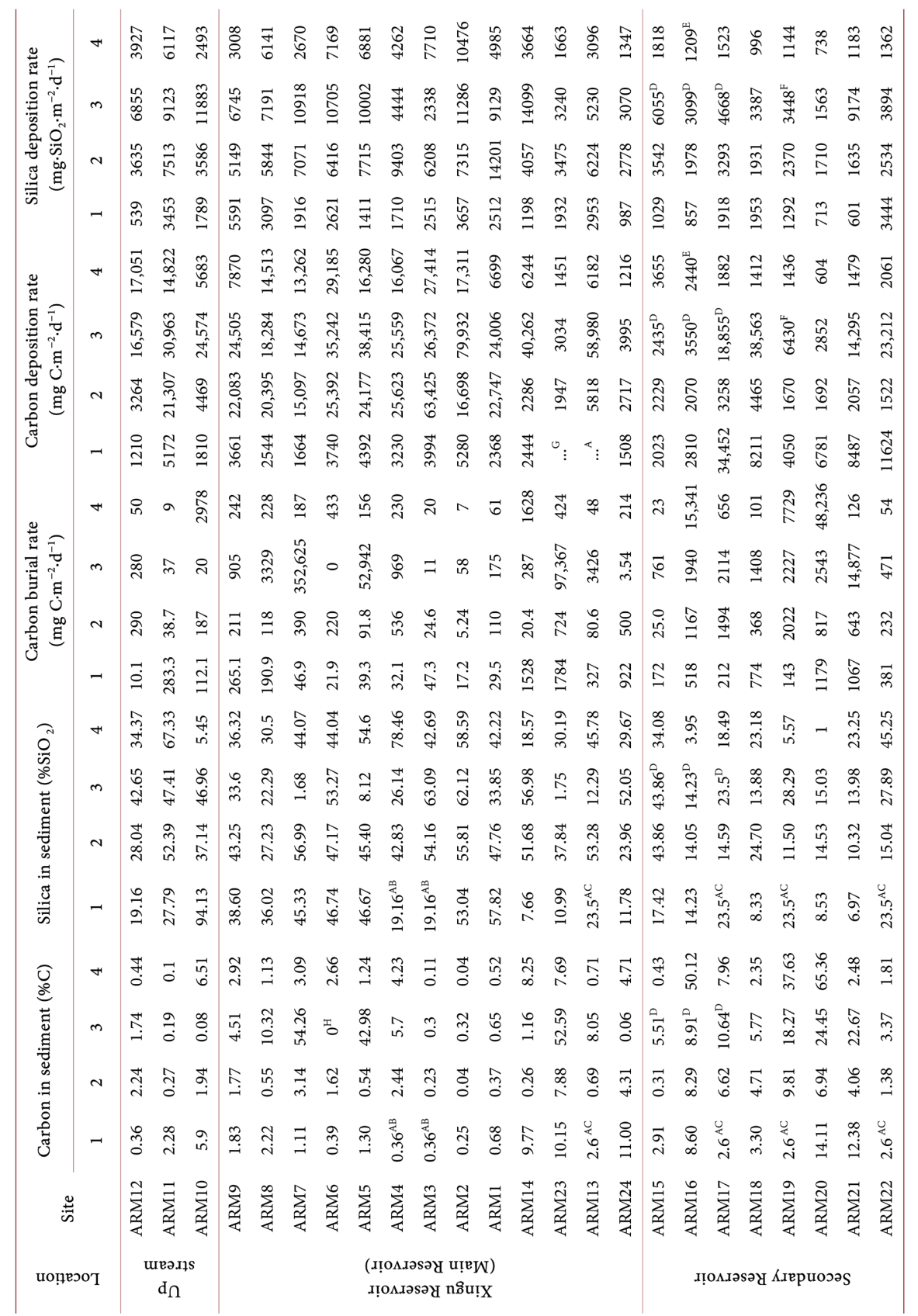

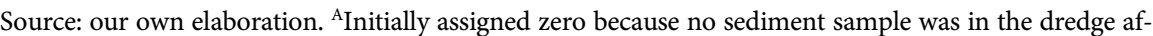
ter executing the sediment sampling procedure. While discussing zero values one of us-statistician J. P.P. Dias-made the rather disconcerting assertion that "zero values had to be measured", a condition with which we complied from there on. ${ }^{B}$ Plugged with a low value measured upstream at site ARM12. ${ }^{C}$ Median of 18 samples collected during this survey from 18 sites. ${ }^{D}$ Site not measured because of boggled air logistics one day before survey commencement. Plugged with interpolated figure based on moving averages of measured sites. ${ }^{\mathrm{E}}$ Traps, whether tampered with or lost, were not found upon retrieval. Plugged with interpolated figure based on moving averages of measured sites. ${ }^{\mathrm{F} T r a p s}$ were not found, possibly carried away by the strong water flow. Plugged with interpolated figure based on moving averages of measured sites. ${ }^{\mathrm{G}}$ Trap was lost. ${ }^{\mathrm{H}}$ Below detection limit of the analytical balance. 
Table S3. Carbon burial efficiencies (\%) at measured sites during the four field surveys and medians of sampled environments.

\begin{tabular}{|c|c|c|c|c|c|c|}
\hline \multicolumn{2}{|c|}{ Environment } & Site & CBE1 & CBE2 & CBE3 & CBE4 \\
\hline \multirow{2}{*}{\multicolumn{2}{|c|}{$\begin{array}{c}\text { Upstream } \\
\text { (median 1.3) }\end{array}$}} & ARM12 & 0.83 & 8.88 & 1.69 & 0.29 \\
\hline & & ARM11 & 5.48 & 0.18 & 0.12 & 0.06 \\
\hline & & ARM10 & 6.19 & 4.18 & 0.08 & 52.4 \\
\hline \multirow{13}{*}{$\begin{array}{l}\text { Main Reservoir } \\
\text { (median 1.4) }\end{array}$} & Main and Secondary & ARM9 & 7.24 & 0.96 & 3.69 & 3.07 \\
\hline & $\begin{array}{c}\text { Reservoirs } \\
\text { (median 3.7) }\end{array}$ & ARM8 & 7.50 & 0.58 & 18.2 & 1.57 \\
\hline & & ARM7 & 2.82 & 2.58 & 2403 & 1.41 \\
\hline & & ARM6 & 0.59 & 0.87 & 0.00 & 1.48 \\
\hline & & ARM5 & 0.89 & 0.38 & 138 & 0.96 \\
\hline & & ARM4 & 0.99 & 2.09 & 3.79 & 1.43 \\
\hline & & ARM3 & 1.18 & $\ldots$ & 0.04 & 0.07 \\
\hline & & ARM2 & 0.33 & 0.03 & 0.07 & 0.04 \\
\hline & & ARM1 & 1.25 & 0.48 & 0.73 & 0.91 \\
\hline & & ARM14 & 62.5 & 0.89 & 0.71 & 26.1 \\
\hline & & ARM23 & $\ldots$ & 37.2 & 3209 & 29.2 \\
\hline & & ARM13 & $\ldots$ & 1.39 & 5.81 & 0.78 \\
\hline & & ARM24 & 61.1 & 18.4 & 0.09 & 17.6 \\
\hline \multirow{8}{*}{$\begin{array}{c}\text { Secondary } \\
\text { Reservoir } \\
\text { (median 16.3) }\end{array}$} & & ARM15 & 8.50 & 1.12 & 31.3 & 0.63 \\
\hline & & ARM16 & 18.4 & 56.4 & 54.6 & 629 \\
\hline & & ARM17 & 0.62 & 45.9 & 11.2 & 34.9 \\
\hline & & ARM18 & 9.43 & 8.24 & 3.65 & 7.15 \\
\hline & & ARM19 & 3.53 & 121 & 34.6 & 538 \\
\hline & & ARM20 & 17.4 & 48.3 & 89.2 & 7986 \\
\hline & & ARM21 & 12.6 & 31.3 & 104 & 8.52 \\
\hline & & ARM22 & 3.28 & 15.2 & 2.03 & 2.62 \\
\hline
\end{tabular}

...non existent data. 